\title{
Assessing international accounting harmonization in Latin America
}

\author{
Juarez CARNEIRO \\ Fundação Brasileira de Contabilidade \\ St. de Industrias Graficas 1 495/505/515 Ed. \\ Barão do Rio Branco 1 \\ Zona Industrial \\ Brasília DF, 70610-410, Brasil \\ Email: juarez@fbc.org.br \\ Lúcia Lima RODRIGUES \\ GOVCOPP \\ University of Minho, Portugal \\ Email: lrodrigues@eeg.uminho.pt \\ Russell CRAIG* \\ Portsmouth Business School \\ University of Portsmouth \\ Richmond Building, Portland Street \\ Portsmouth, Hampshire PO1 3DE, UK \\ Email: Russell.Craig@port.ac.uk \\ * Corresponding author
}




\title{
Assessing international accounting harmonization in Latin America
}

\begin{abstract}
We draw on institutional theory and interviews with key informants to assess international accounting harmonization in the 13 countries of the Group of Latin American Accounting Standards Setters (GLASS). Some GLASS countries have effected full formal adoption of International Financial Reporting Standards (IFRS), but in others, IFRS are not permitted. In several GLASS countries, IFRS are supplemented by national standards for micro-entities and cooperatives. We conclude that it will be difficult to achieve material harmonization in GLASS countries due to a lack of trained accountants, unreliable enforcement systems, and competing institutional logics of taxation systems, banks and insurance companies.
\end{abstract}

Keywords: Latin America; IFRS; accounting harmonization; change; resistance JEL Codes: M41, M48, 054, 057

\section{Introduction}

We compare the process of adopting (and/or converging with) International Financial Reporting Standards (IFRS) ${ }^{1}$ by countries in Latin America. Our focus is on the countries that compose the Group of Latin American Accounting Standards Setters (GLASS). This organization was formed in 2011. The interviews conducted for the present study were undertaken in 2013, when GLASS comprised 12 countries (Argentina, Bolivia, Brazil, Chile, Colombia, El Salvador, Ecuador, Mexico, Panama, Peru, Uruguay, and Venezuela). Guatemala had observer status at that time and its representative was also interviewed. Subsequently, Guatemala became a full member, as did Costa Rica and Honduras.

There is little published research on accounting in the GLASS countries. Indeed, little is known outside each national setting of the process of adoption or convergence with IFRS in Latin America. Generally, we seek to extend knowledge on this matter by addressing the following four sets of specific research questions:

1. How and why was GLASS formed? Who was the institutional entrepreneur?

2. How can the current stage of IFRS adoption or convergence in each GLASS member country be characterized? Using a conceptual framework based on institutional theory, how can accounting harmonization be explained? What agreements between competing viewpoints have been achieved?

3. Were the adoption and convergence processes isomorphic? Which institutional logics were central in these processes?

4. Does the degree of adoption or convergence depend on whether knowledge discourses about IFRS become power? Who were the institutional actors? What are the main sources of resistance?

We interviewed the official representative of each of the 13 GLASS countries in September 2013. To increase reliability, the interview data are triangulated with other evidence (such as archival documents and website information). We explore the process of international adoption or convergence from an institutional perspective. Our intent is to

\footnotetext{
${ }^{1}$ This acronym also refers to accounting standards issued by the International Accounting Standards Board (IASB).
} 
understand how accounting influences, and is influenced by, multiple agents, institutions, and processes (Miller, 1994; Miller and Napier, 1993). We invoke institutional theory because we are attracted to its arguments that efficiency is not sufficient to explain changes in accounting practices (DiMaggio and Powell, 1983; Scott and Meyer, 1991; Rodrigues and Craig, 2007) and that organizations (or in this case countries) adhere to external rules, norms and belief systems to garner legitimacy and an aura of rationality and efficiency (Carpenter and Feroz, 1992).

Our macro-institutional analysis occurs at the organizational field level (Dillard et al., 2014) to enhance understanding of agreements that have been achieved in GLASS countries. Some GLASS countries have effected full formal harmonization with IFRS, while in others, IFRS are not permitted, but are only used by a limited number of companies in preparing consolidated accounts. We reveal that material harmonization, as opposed to formal harmonization (Fontes et al., 2005), will be difficult to achieve in coming years because of a lack of trained professional accountants and reliable enforcement systems. Using an institutional perspective and the theoretical framework of Rodrigues and Craig (2007), we find that GLASS countries are at different stages of the adoption/convergence process.

In several countries, in addition to full IFRS and the IFRS for Small and Medium-sized Entities (SMEs), other national standards have been issued for micro-entities and cooperatives. Thus, in national contexts where these types of entities are important, local standards are being issued. Such practice diverges from the institutional logic regarding the appropriateness of standards issued by the IASB for any entity, in different parts of the world. We also find that competitive institutional logics related to taxation systems, and the banking and insurance industries, are important influences in some countries, and that they are delaying the adoption/convergence process.

The next section presents a literature review in two sections: a review of aspects of accounting harmonization globally and in Latin America; and a theoretical framework based on institutional theory. Next, we present the research method and results, before entering conclusions.

\section{Literature review}

\subsection{Financial reporting harmonization globally and in Latin America}

Because institutional contexts differ, it is difficult to accommodate accounting diversity and achieve international accounting harmonization. Environmental factors vary widely globally, but play an important role in explaining accounting practices (Radebaugh et al., 2006). The imposition of Anglo-Saxon accounting models on nations with different levels of development and different economic, social, political and cultural context, has been criticized. However, arguments against harmonization were weakened when the IASB began to gain enhanced legitimacy in the mid-1990s. The process of accounting harmonization began to develop more vigorously as regional and national accounting standards setters, and Big 4 audit firms, began to support the IASB more strongly.

The success of IFRS is attributed to its principles-based standards (Carmona and Trombetta, 2008). This feature gives IFRS flexibility and helps them adapt to different institutional contexts and accounting traditions. Despite widespread international adoption of IFRS, there are conflicting opinions about the ensuing quality of financial reporting. Carmona and Trombetta $(2008$, p. 458) contend that quality depends on whether the adoption is serious or countries are "label adopters": that is, they seek the reputational cachet of IFRS, but do not innately and fully commit to them. Thus, some companies take advantage of the flexibility of 
IASB standards to maintain the previous national regulation, but are classified nonetheless as using international standards (Guerreiro et al., 2015).

One of the few studies of accounting practice in Latin America (by Sarquis et al., 2014) reported on accounting systems in Argentina, Brazil, Chile Mexico and Peru - all countries that had adopted IFRS. They concluded that despite efforts to adopt or to converge with IFRS, there were significant differences in the way IFRS were applied, resulting in "national IFRS standards." Sarquis et al. (2014) concluded that the traditional dichotomy between AngloSaxon and Continental European countries remained, even after the adoption of IFRS.

Several studies have analyzed earnings management practices in Latin America. Rathke and Santana (2015), for example, studied whether earnings management by listed companies in Brazil, Chile and Peru increased or decreased after the adoption of IFRS. They concluded that accounts manipulation was reduced, financial information was more homogeneous, earnings management was reduced, and the quality of financial information was improved. Rodríguez García et al. (2017) analyzed 923 listed companies from Argentina, Brazil, Chile, and Mexico. They concluded that between 2000 and 2014, change from local accounting regulations to IFRS increased value relevance and earnings timeliness in large firms. Silva et al. (2015) concluded that the adoption of IFRS in Brazil and Chile between 2004 and 2012 reduced earnings management, although the effect was only significant for Chilean companies. In view of the above, the general effect of IFRS adoption on listed companies seems to have been positive.

\subsection{Theoretical framework}

The theoretical framework of Rodrigues and Craig (2007) is used for interpretative purposes, together with the concepts of institutional logics (Anglo-Saxon versus Latin accounting standards) and institutional entrepreneurship (who initiated GLASS and pushed for change from local standards to international standards in each country?). We have changed the framework used by Rodrigues and Craig (2007) by replacing the dialectical process of thesis, antithesis and synthesis with the concept of institutional logics. We argue that to understand the process of international accounting harmonization, four circumstances should be considered.

1. Convergence of accounting standards depends on achieving agreements between competing institutional logics.

Guerreiro et al. (2012a) argue that institutional logics associated with the use of IFRS enable and constrain organizational decisions regarding generally accepted accounting principles (GAAP). Institutional logics are "the socially constructed, historical patterns of material practices, assumptions, values, beliefs and rules by which individuals produce and reproduce their material subsistence, organize time and space, and provide meaning to their social reality" (Thornton \& Ocasio, 1999, p. 804). Rodrigues and Craig (2007) identified several sources of beliefs associated with the adoption of IFRS. These included the need to increase the efficiency of capital markets, improve the comparability of financial information, and reduce capital costs. Harmonization through adoption of IFRS has multiple advantages for multinational corporations and capital market regulators: cost reduction, improved understanding, credibility and comparability of financial information, and the offering of an alternative to standards set by the US Financial Accounting Standards Board (FASB).

But society is conceptualized as a potentially contradictory inter-institutional system in which each sector represents a different set of expectations of social behaviour (Friedland \& Alford, 1991). Fields are comprised of multiple logics, and by debate about which practices are 
appropriate (Lounsbury, 2007; 2008). Beliefs associated with maintaining national accounting standards are that they are adapted to the national environmental context and privilege the most important users in the country (creditors and the tax system) and not secondary users (underdeveloped capital markets in some countries). Standards used in advanced economies do not axiomatically serve less developed countries well. They are prone to impose an AngloAmerican hegemony.

Change is explained by differences in cognitive orientation and by debate about which practices are appropriate (Lounsbury, 2007, 2008; Guerreiro et al., 2012a). Each institutional logic offers multiple sources of rationality (Thornton \& Ocasio, 2008).

The creation and adoption of IFRS is based on prevailing institutional logics in which the interests, identities, values and assumptions of individuals and organizations are embedded (Thornton \& Ocasio, 2008; Guerreiro et al., 2012a). Thus, in analysing the creation of GLASS and the adoption of IFRS in GLASS countries, we consider the institutional logics involved. In doing so, we incorporate the role of broader belief systems into our examination of the willingness of countries to conform to institutional pressures. In institutional theory, organizational fields are comprised of multiple logics. Practice variation is explained by differences in cognitive orientation and by debate about which practices are appropriate (Lounsbury, 2007; 2008). In explaining the adoption/convergence process in GLASS countries, we are alert to the heterogeneity in accounting practices and the agency that arises from contradictions between the logics of different institutional orders that provide multiple sources of rationality (Thornton \& Ocasio, 2008; Guerreiro et al., 2012a). Governments, accounting standards setters, and associations of accountants, have their own lower-order logics. These are nested in society-level logics. Lower-order logics such as common-law (IFRS) versus code-law logics (national accounting and taxation standards) help to prescribe local accounting practices and understand the agreements we analyse.

Thus, the degree of adoption (or convergence) by GLASS countries should be consistent with the competing institutional logics of each country. The adoption/convergence process should vary between "full and immediate adoption of IFRS; full adoption of IFRS with time lags; selective adoption of IFRS; and the development of national standards based on IFRS" (Rodrigues \& Craig, 2007, p. 753).

\section{Adoption and convergence of accounting standards is a process of isomorphism that works well when institutions and environments are similar}

IFRS can be legally enforced by regulatory agencies in different countries. This is coercive isomorphism. Normative isomorphism can be seen in the rhetoric of large international accounting firms who advise their company clients to adopt IFRS; in the teaching of IFRS at universities; and in the rhetoric of national and global professional accounting associations in supporting adoption of IFRS. Several companies have adopted IFRS voluntarily for competitive reasons and to attain legitimacy (Guerreiro et al., 2012a; 2012b). This is mimetic isomorphism. However, high quality isomorphism will only be possible if institutions and contexts are similar (Rodrigues \& Craig, 2007). Although all GLASS countries can be classified as Latin, the cultures, social contexts and social understandings of rationality differ between them.

\section{Convergence in different environmental contexts is likely to be affected by decoupling}

The more diversified the environment where companies are located, the more likely they are to operate differently, and for financial reporting standards to apply differently (Zeff, 2007). Decoupling, or idiosyncratic national interpretations, should be observable. These arise 
from institutional pressures to adopt international accounting standards that differ from national standards. Decoupling can arise too from cultural barriers in understanding the AngloAmerican accounting model; difficulties in conveying intended meaning in translating of standards; poorly prepared professional accountants; and the complexity of implementing IFRS. Thus, although companies can argue that they are applying IFRS, full compliance may not be achieved.

4. The degree of convergence will depend on whether knowledge of the discourse of IFRS by institutional entrepreneurs becomes power

The institutionalization of supranational accounting standards is a deeply political activity, reflecting the relative power of organized interests and actors (Dillard et al., 2004). Adoption and convergence (or isomorphism) with IFRS should occur if institutions believe that convergence offers the best course of action and is conceived as right and normal. These discourses are used by institutional entrepreneurs: that is, by organized actors with the interests, and resources to create new institutions or transform existing institutions (Maguire et al., 2004). Battilana et al. (2009) specified that institutional entrepreneurs must initiate divergent changes that break with institutionalized models and institutional logics in a given context; and that they must mobilize resources to implement these changes - thus contributing to the institutionalization of alternative practices.

Three activities to effect change are first, to develop a shared vision and powerknowledge discourse (which involves theorizing the institutional design to take into account the interests, values, and problems of potential allies); second, to mobilize people to support and accept new routines; and third, to motivate others to achieve and sustain the accounting change.

\section{Research method}

To understand the institutional dynamics associated with the adoption of, or convergence with, IFRS in GLASS countries, we conducted semi-structured interviews with the national representative of each of the 13 GLASS countries, in September 2013. We used key informant interviews because they are an effective way of gaining deeper knowledge of the group processes and perspectives of different actors (Patton, 2002; Guerreiro et al., 2015). Key informant interviews are qualitative in-depth interviews that permit collection of information from a wide range of people who have first-hand knowledge of the accounting community. The interviews were conducted and transcribed in the native language of the key informants (Spanish or Portuguese). Each interviewee received their interview transcript to check for possible mistakes or misinterpretations. When an interviewee's answers were less clear, additional clarifications were requested. The duration of each interview was between 30 and 90 minutes.

Information pertaining to the organizations represented by each interviewee was collected in advance to increase interviewer credibility and win the confidence of key informants. A list of interview topics was sent to key informants in advance to enable them to begin preparing their responses, and if necessary, to discuss the topic with the accounting association they represent in GLASS. We agreed to disclose only the key informants' positions in GLASS, and the name of the professional associations to which they belonged. Interview data were coded according to a scheme developed in concert with the theoretical framework. Table 1 shows the key informants' positions in GLASS and the respective accounting bodies they represented. 
Table 1

\section{Key informant details}

\begin{tabular}{|l|c|}
\hline \multicolumn{1}{|c|}{ Position } & Country \\
\hline $\begin{array}{l}\text { Vice-President of GLASS, Director of the Argentine Association of Accountants, Economists, } \\
\text { Managers and Actuaries }\end{array}$ & Argentina \\
\hline Director of GLASS, President of the Mexican Accounting Standards Board & Mexico \\
\hline Member of GLASS, Director of the Accounting Standards Board of Peru & Equator \\
\hline Director of GLASS, President of the Colombian Accounting Standards Board & Colombia \\
\hline Director of GLASS, Director of the Association of Accountants Economists and Managers of Uruguay & Uruguay \\
\hline Member of GLASS, Vice-President of the Brazil Federal Council of Accounting & Chile \\
\hline Member of GLASS, Director of the Association of Accountants of Chile & Bolivia \\
\hline Member of GLASS, Director of the Association of Auditors and Certified Accountants of Bolivia & Guatemala \\
\hline Member of GLASS, President of the Institute of Certified Accountants and Auditors of Guatemala & Panama \\
\hline Member of GLASS, Director of the Accounting Standards Board of Panama & El Salvador \\
\hline Member of GLASS, Director of the Association of Accountants of El Salvador & Peru \\
\hline Member of GLASS, Director of the Accounting Standards Board of Peru & Venezuela \\
\hline Director of GLASS, Director of the Federation of Colleges of Public Accountants of Venezuela & Bata \\
\hline
\end{tabular}


When GLASS was formed, the national representatives on GLASS represented the body in their country that issued financial reporting standards. If such a body did not exist, the representative was a member of a professional body that formally issued financial reporting standards and was also a member of the International Federation of Accountants (IFAC) (as was the case with Brazil and Chile). If the previously mentioned bodies did not exist (or they did not agree to join GLASS), the country's professional accounting body that was a member of IFAC became a member of GLASS. ${ }^{2}$

To overcome the limitations of single source information, and to increase reliability and validity, interviews were complemented with documentary evidence. Such a combination of data sources increases the robustness of conclusions (Patton, 2002). The documentary evidence consists of reports published by professional bodies in GLASS countries; documents disclosed on web sites (including the websites of GLASS ${ }^{3}$, and the IFRS Foundation ${ }^{4}$ ), laws and legislation. These additional sources increase the internal and contextual validity of the data (Ryan et al., 2002) and the research quality. This process led to construction of tables that classified the subjects and topics addressed most frequently by the respondents. Relationships between themes were established through a close reading of data and documents that was articulated with the theoretical approach adopted. Particular attention was paid to the extent to which respondents accepted, or challenged, the adoption of IFRS.

\section{Results}

Below we analyse the interview data and the documentary evidence gathered, for each set of research questions.

1. How and why was GLASS created? Who was the entrepreneur?

In February 2011, the Brazilian accountants association, the Federal Council of Accounting (CFC), held a seminar on the "State of the IFRS Convergence Process in Latin American Countries" in Brasilia. Other countries represented were Argentina, Mexico, Venezuela and Uruguay. The [then] president of the IASB, Sir David Tweedie, also attended. This was the first formally convened meeting to discuss the constitution of GLASS. Each country reported on the status of its adoption of IFRS. The meeting discussed the ways GLASS could contribute to develop various accounting themes proposed by the IASB. Tweedie reported that many countries now communicated with the IASB through regional blocks, such as the European Financial Reporting Advisory Group (EFRAG), Asian-Oceanian Standard-Setters Group (AOSSG), and the Pan African Federation of Accountants (PAFA). Because these regional blocks facilitated communication and consensus on accounting issues, the IASB suggested that a regional group be created to represent Latin American countries in the IASB. This idea was based on the premise that countries with similar cultural contexts would have similar issues to address in adopting IFRS.

In 2011, the CFC convened two meetings in Brasilia and two meetings in Buenos Aires to develop the constitution of GLASS. On 28 June 2011, during the "Accounting and Accountability for Regional Economic Growth" conference in Buenos Aires, the statutes of

${ }^{2}$ http://media.ifrs.org/2014/Trustees/October/GLASS\%20Presentation\%20English\%202014.pdf, accessed 3 December 2016.

${ }^{3}$ http://glenif.org/es/, accessed 20 November 2016.

${ }^{4}$ http://www.ifrs.org/Use-around-the-world/Documents/Jurisdiction-profiles, accessed 20 December 2016. 
GLASS were signed. Four directors were elected (the representatives of Mexico, Uruguay, Chile and Venezuela), together with a Vice-President (an Argentinian), and a President (a Brazilian).

The creation of GLASS was a strong normative initiative of the IASB, acting as an institutional entrepreneur (Battilana et al., 2009; Battilana, 2006). GLASS disseminated IASB standards and thereby reconciled competing institutional logics. Regional groups such as GLASS facilitated the process of changing local standards to international standards, thereby increasing normative isomorphism and power-knowledge discourses in support of IFRS. Divergent change was also driven by dominant actors in mature fields when some established practices and forms of action (local standards) were questioned. In this case, dormant institutions (local standards) changed to international standards (Greenwood \& Suddaby, 2006). The IASB's support of GLASS was influenced by its perception that Latin America comprised fragmented institutional environments and multiple logics. This encouraged the IASB to act as an institutional entrepreneur to effect change from national standards to IFRS.

Actors associated with the accounting profession in Brazil and Argentina were involved strongly in creating GLASS as a regional accounting standardization body. GLASS offered an easier way of communicating knowledge of IFRS, using a network of professionals who would also help to disseminate IFRS. It also provided a technical regulatory forum in which IFRS could be discussed.

The creation of GLASS can also be conceived as mimetic isomorphism. Prior to its formation, similar bodies existed in Europe and elsewhere. By establishing GLASS, Latin America was creating a type of organization that had been considered successful and legitimate in other parts of the world (DiMaggio \& Powell, 1983). Thus, the establishment of GLASS permitted "regional harmonization of accounting standards .... with institutions like the IASB serving as a guiding mechanism or clearing house" (Rodrigues \& Craig, 2007, p. 750). However, GLASS was a late adopter - a timing that can be explained principally for reasons of legitimacy-seeking rather than efficiency (Dillard et al., 2004).

2. How can the current stage of IFRS adoption or convergence in each GLASS member country be characterized? Using a conceptual framework based on institutional theory, how can accounting harmonization be explained? What agreements between competing points have been achieved?

The situation in each GLASS country is summarized in Table 2 and described below.

Argentina: The National Securities Commission (CNV) required all companies (other than banks or insurance companies) whose securities are publicly traded, and which are regulated by the CNV, to prepare consolidated and separated financial statements using IFRS. The use of IFRS for local statutory purposes by unlisted companies is determined by each province's Registry of Commerce. ${ }^{5}$ When the IFRS for SMEs is not permitted, companies are expected to use Argentinian standards. Argentina is converging Argentinian GAAP with IFRS. The Argentinian representative considered the completion of a set of professional accounting rules that were harmonized with the international accounting standards proposed by the IASB to be an urgent priority. The Accounting Standard 24 (RT 24) "Particular aspects of accounting and audit for cooperative entities" was issued in $2008 .^{6}$

\footnotetext{
${ }^{5}$ Argentina has 23 provinces and one equivalent province (the autonomous city of Buenos Aires).

6 http://www.cpcesfe1.org.ar/resol-CS/RT24\%20NormContcooperat\%20JGmarzo08\%20pararesol.pdf, accessed 3 January 2017.
} 
Bolivia: The National Technical Board of Auditors and Accountants had planned the adoption of IFRS since 2009. However, implementation was reported as awaiting approval by the government regulatory body that approves accounting standards (Ministry of Development and Economic Growth). Only a few companies had adopted IFRS voluntarily. Currently, all companies in Bolivia, whether domestic or foreign, must follow Bolivian Accounting Standards in preparing statutory financial statements. Subsidiaries of foreign companies (whether Bolivian or foreign companies themselves) are permitted to use IFRS for consolidation purposes (but not in their separate company financial statements).

Bolivia has no general plan for the diffusion of IFRS. Few professional accountants have adopted IFRS. The convergence process in Bolivia received a boost in January 2007 with the support of the Inter-American Development Bank (IDB) (Project ATN/MT-10078-BO: Convergence with International Accounting Standards and Audit). The key informant from Bolivia indicated that "government authorities have not agreed, and so the 14 Bolivian accounting standards continue to be followed, with IFRS applied only on a supplementary basis."

Brazil: Full IFRS are required for the consolidated financial statements of listed companies for financial years ending on or after 31 December 2010. Separate financial statements of listed companies follow Brazilian Generally Accepted Accounting Principles (BR GAAP). Since 2010, all Brazilian Accounting Standards have converged with IFRS. For unlisted companies for financial reporting years ending on or after 31 December 2010, financial statements must be prepared in accord with BR GAAP. However, unlisted companies are permitted to adopt IFRS for their consolidated financial statements.

Although SMEs are required to apply the Brazilian equivalent of the IFRS for SMEs, they can opt to apply full BR GAAP. Since 2010, listed financial institutions, or unlisted financial institutions that are required to have an audit committee regulated by the Brazilian Central Bank (BACEN), have been required to prepare consolidated financial statements in accord with IFRS, as supplemental information. Statutory accounts are required to follow accounting practices adopted by the Brazilian Central Bank. Insurance companies have been required to prepare consolidated financial statements using IFRS since 2010. From 1 January 2011, for their individual (separate company) financial statements, insurance companies have adopted BR GAAP. Micro-entities use a simplified set of national accounting standards established under a local standard issued by the accountants' association (Resolution CFC 1418/2012).

Chile: On 31 December 2009, major public companies registered with the Superintendence of Securities and Insurance were required to use IFRS. Some companies were allowed to defer adopting IFRS until 2010. Banks and other financial institutions were required to follow accounting rules issued by the Superintendence of Banks and Financial Institutions. This body adopted IFRS from 31 December 2009, with modifications (e.g., not permitting fair value). Effective in 2013, Chile adopted the IFRS for SMEs. Support of the IDB was important for the adoption process.

Colombia: Three requirements of Law 1314 of 13 July 2009 are outlined below:

1. In 2015 (transition date 2014), full IFRS were to be adopted by all companies whose securities are publicly traded and are legally defined as public interest entities under the law; by large companies whose parent or subsidiary reports under IFRS; and companies whose 
revenue is derived $50 \%$ or more from exports or imports. These companies had an option to adopt IFRS earlier, beginning in 2013.

2. In 2016, the IFRS for SMEs standard was to be adopted by large and medium-sized companies other than those included in group 1 above.

3. In 2015, micro-entities were required to adopt a new standard developed for micro entities in Colombia by the Technical Council for Public Accounting. Micro entities could choose the IFRS for SMEs.

Another agreement between competing points was achieved: companies regulated by the National General Accounting Office (because the Colombian Federal Government has an ownership stake) are required to apply IFRS in accord with a new regulatory framework that was issued by Columbia's General Accounting Office in 2014.

Ecuador: Since 1 January 2010, all listed companies and all other companies required by law to have an external audit, have been required to use IFRS. Since 1 January 2011, IFRS have been required by all companies with assets greater than US\$ 4,000,000 at 31 December 2007; holding companies and consolidated groups; state-owned entities; and foreign-invested entities. Since 1 January 2012, all other companies have been required to use IFRS. An exception is allowed for companies with total annual sales less than US\$ 5,000,000; and total assets less than US\$ 4,000,000, and fewer than 200 employees (annual weighted average). These companies may use the IFRS for SMEs. Banks, insurance companies, and other financial institutions under the supervision of the Superintendence of Banks and Insurance Companies must use standards issued by that regulator.

El Salvador: In 2011, the Supervisory Board of the Profession of Public Accounting and Auditing decreed that IFRS be adopted by companies listed on the El Salvador Stock Exchange. The IFRS for SMEs was to be used by all other companies. The decree did not apply to banks, insurance companies, and pension funds which are subject to accounting regulations adopted by their respective regulatory agencies. These regulators have not adopted IFRS. They require the financial statements of their regulated entities to show the main differences between local standards and IFRS. Cooperatives have to comply with a special accounting standard based on the IFRS for SMEs.

Guatemala: IFRS were adopted commencing in 2008, and the IFRS for SMEs in 2010. However, both are still voluntary since resolutions of the College of Public Accountants and Auditors of Guatemala do not have legal force. Companies prefer to prepare financial statements based on the tax law (Guatemala Commercial Code Law). However, the tax authority will also accept financial statements prepared according to either full IFRS or the IFRS for SMEs. Banks, insurance companies, and other regulated financial enterprises are not allowed to present their financial statements based on IFRS. Instead, the banking regulator has developed national accounting manuals containing some accounting treatments that differ from IFRS. In Guatemala, accounting is generally subordinated to taxation.

Mexico: IFRS were adopted by the National Banking and Securities Commission (NBSC) for listed companies other than financial institutions and insurance companies, effective for annual reporting periods (non-consolidated and consolidated accounts) beginning on or after 1 January 2012. Early application was allowed from 2008. Companies in the financial and insurance sectors follow Mexican Financial Reporting Standards (MFRS), requirements of the NBSC, and of the National Insurance and Bonding Commission (CNSF). Additionally, the 
Mexican Financial Reporting Standards Board (CINIF) has a convergence project to eliminate differences between MFRS and IFRS. MFRS are used by most SMEs. CINIF has not adopted the IFRS for SMEs. CINIF has identified the main differences between the MFRS and IFRS. Several changes to IFRS have been made.

Panama: The Superintendence of Banking (by Agreement 4, 11 May 1999) and the National Securities Commission (by Resolution 8, 22 May 2000) require either IFRS or US GAAP to be adopted in preparing financial statements for banking entities and companies registered with the National Securities Commission. Law 12 (3 April 2012) required all insurance companies to use IFRS from 2014. Panama is a case of early full adoption. The Fiscal Code was adjusted in 2005 (Article 699). Article 14 of Law 57 (the Law of Certified Public Accountants) was also changed in 2005 to require use of IFRS. SMEs are permitted, but not required, to use IFRS for SME. Alternatively, SMEs may choose IFRS or national accounting standards issued by the Accounting Technical Board of the Ministry of Finance.

Peru: Since 1 January 2012, the Peruvian securities market regulator has required all listed companies other than financial institutions (banks, insurance companies, pension funds) to publish financial statements prepared in conformity with IFRS. In 2013, unlisted larger private companies (those with net revenues or assets exceeding approximately US\$ 40 million) were required by the Accounting Standards Council (CNC) to publish financial statements prepared in accord with IFRS. The CNC indicated that the IFRS for SMEs may be applied by Peruvian companies with total assets and/or net revenues less than approximately US\$4 million.

Companies applying IFRS must comply with some national legal and tax requirements that might be inconsistent with IFRS. These include tax regulations for determining the useful lives of depreciable assets and the restatement of financial statements for inflation between 1998 and 2004. (This is despite the Peruvian economy not qualifying as hyperinflationary under IAS 29 Financial Reporting in Hyperinflationary Economies.) Accounting standards for banks are in the process of being converged with IFRS.

Uruguay: In July 2007, the government decreed that IFRS would be mandatory for all companies other than banks and financial institutions for financial years beginning on or after 1 January 2009. However, adoption was not full, since three major changes were introduced. First, companies must follow national standards for the presentation of financial statements and note disclosures that differ from IAS 1 Presentation of Financial Statements. Second, general price-level adjusted financial statements were required even if the hyperinflation test of $100 \%$ over three years (IAS 29 Financial Reporting in Hyperinflationary Economies) is not met. Third, investments must be accounted for by the equity method in separate financial statements. (This differs from the requirement in IAS 27 Separate Financial Statements.)

In April 2011, the government decreed that IFRS should be used in 2012 by non-financial institutions whose securities are publicly traded - and by autonomous entities, and decentralised service companies. In April 2012, the government decreed that financial statements adjusted for changes in the general price-level would not be mandatory after 2011. For banks, insurance companies, mutual funds, and other financial institutions, the Central Bank of Uruguay required unmodified adoption of IFRS, starting in 2014. Decree 291/2014 required the IFRS for SMEs be applied by SMEs (with modifications, such as revaluation model for property, plant and equipment and capitalisation of borrowing costs are permitted) whose annual net operating income was less than UR\$ 200,000 (approximately US\$ 6,300) and for whom total indebtedness to entities controlled by the Central Bank of Uruguay was less than 
$5 \%$ of net asset value. SMEs meeting these requirements were also permitted to apply full IFRS instead of the IFRS for SMEs. The key informant from Uruguay advised that an update of IFRS and an accounting standard for micro-entities were under consideration by the government's Standing Committee for Accounting Standards Adaptation.

Venezuela: The 2008 version of IFRS was adopted, but as modified by the Federation of Public Accounting Societies of Venezuela. One major modification was that price-level adjusted financial statements are required when the rate of inflation is $10 \%$ or more. This requirement was for all companies whose securities trade in a public market, and for banks and other financial institutions. New and amended IFRS since 2008 have not been adopted. SMEs not in the oil, energy, and mining industries, were required to use the IFRS for SMEs from 2010 onwards. The definition of small and large companies has changed over time.

The preceding analysis reveals that countries are at different stages in the process of adoption or convergence with IFRS. The date of adoption/convergence differs from country to country. In some countries, despite adoption, IFRS are not up to date. In most countries, the adoption by financial institutions is problematic. Some countries have needed to create other standards, such as of a local accounting standard for micro-entities and an accounting standard for cooperatives. When IFRS are permitted (but not required), only a few companies adopt them. While some countries adopted IFRS in 2005 (e.g., Panama), others faced powerful "tax mentality" logics that prevented them from changing from local standards to IFRS. 
Table 2

The IFRS adoption and convergence in GLASS countries

[Abbreviations: Acctg = Accounting; Stds $=$ Standards $]$

\begin{tabular}{|c|c|c|c|c|c|c|}
\hline Country & $\begin{array}{l}\text { Listed } \\
\text { companies }\end{array}$ & $\begin{array}{l}\text { Unlisted } \\
\text { companies }\end{array}$ & $\begin{array}{l}\text { Banks and } \\
\text { insurance } \\
\text { companies }\end{array}$ & $\begin{array}{l}\text { IFRS for } \\
\text { SMEs }\end{array}$ & $\begin{array}{l}\text { Micro- } \\
\text { entities } \\
\text { standard }\end{array}$ & $\begin{array}{l}\text { Cooperatives } \\
\text { standard }\end{array}$ \\
\hline Argentina & IFRS & $\begin{array}{l}\text { IFRS converged } \\
\text { with Argentine } \\
\text { GAAP. Full IFRS } \\
\text { and IFRS for } \\
\text { SMEs } \\
\text { permitted. }\end{array}$ & $\begin{array}{l}\text { Regulations } \\
\text { enforced by } \\
\text { Central Bank of } \\
\text { Argentina and by } \\
\text { Superintendence } \\
\text { of Insurance. IFRS } \\
\text { not permitted. }\end{array}$ & No & No & $\begin{array}{l}\text { Acctg Std 24: } \\
\text { Particular aspects } \\
\text { of acctg and audit } \\
\text { for cooperative } \\
\text { entities }\end{array}$ \\
\hline Bolivia & $\begin{array}{l}\text { Bolivian Acctg } \\
\text { Stds* }\end{array}$ & $\begin{array}{l}\text { Bolivian Acctg } \\
\text { Stds* }\end{array}$ & $\begin{array}{l}\text { Bolivian Acctg } \\
\text { Stds* }\end{array}$ & No & No & No \\
\hline Brazil & $\begin{array}{l}\text { IFRS required } \\
\text { in } \\
\text { consolidated } \\
\text { accounts. } \\
\text { Brazilian stds } \\
\text { converged } \\
\text { with IFRS } \\
\text { required in } \\
\text { separate } \\
\text { accounts }\end{array}$ & $\begin{array}{l}\text { Brazilian stds } \\
\text { converged with } \\
\text { IFRS }\end{array}$ & $\begin{array}{l}\text { Listed and large } \\
\text { unlisted banks } \\
\text { and insurance } \\
\text { companies } \\
\text { required to } \\
\text { prepare } \\
\text { consolidated } \\
\text { financial } \\
\text { statements in } \\
\text { accord with IFRS } \\
\text { as supplemental } \\
\text { information. } \\
\text { Statutory } \\
\text { accounts to } \\
\text { follow acctg stds } \\
\text { of Brazilian } \\
\text { Central Bank. }\end{array}$ & $\begin{array}{l}\text { Modified IFRS } \\
\text { for SMEs }\end{array}$ & $\begin{array}{l}\text { Yes. A } \\
\text { simplified set } \\
\text { of acctg stds } \\
\text { established } \\
\text { by Resolution } \\
\text { CFC } \\
1418 / 2012\end{array}$ & $\begin{array}{l}\text { NBC T } 10- \\
\text { Particular acctg } \\
\text { topics of specific } \\
\text { entities, } \\
\text { NBC T } 10.8 \text { - } \\
\text { Cooperative } \\
\text { entities }\end{array}$ \\
\hline Chile & Full IFRS & Full IFRS & $\begin{array}{l}\text { Full IFRS with } \\
\text { adaptations** }\end{array}$ & $\begin{array}{l}\text { IFRS for SMEs } \\
\text { permitted }\end{array}$ & No & No \\
\hline Colombia & Full IFRS & Full IFRS & Full IFRS & IFRS for SMEs & $\begin{array}{l}\text { Financial } \\
\text { acctg stds for } \\
\text { micro entities } \\
\text { in } 2015 \text { (local } \\
\text { standard) }\end{array}$ & No \\
\hline Ecuador & Full IFRS & Full IFRS & $\begin{array}{l}\text { Stds issued by the } \\
\text { Superintendence } \\
\text { of Banks and } \\
\text { Insurance } \\
\text { Companies }\end{array}$ & $\begin{array}{l}\text { IFRS for SMEs } \\
\text { permitted }\end{array}$ & No & No \\
\hline El Salvador & Full IFRS & IFRS for SMEs & $\begin{array}{l}\text { Stds issued by } \\
\text { regulators, } \\
\text { disclosing the } \\
\text { main differences } \\
\text { from IFRS }\end{array}$ & $\begin{array}{l}\text { IFRS for SMEs } \\
\text { permitted }\end{array}$ & No & $\begin{array}{l}\text { Yes, based on IFRS } \\
\text { for SMEs } \\
\text { ("Financial and } \\
\text { Reporting Std for } \\
\text { Cooperative } \\
\text { Associations of El } \\
\text { Salvador") }\end{array}$ \\
\hline Guatemala & $\begin{array}{l}\text { Stds based on } \\
\text { Guatemala }\end{array}$ & $\begin{array}{l}\text { Stds based on } \\
\text { Guatemala }\end{array}$ & $\begin{array}{l}\text { Acctg stds issued } \\
\text { by regulators. }\end{array}$ & $\begin{array}{l}\text { IFRS for SMEs } \\
\text { permitted }\end{array}$ & No & No \\
\hline
\end{tabular}




\begin{tabular}{|c|c|c|c|c|c|c|}
\hline & $\begin{array}{l}\text { Commercial } \\
\text { Code Law. IFRS } \\
\text { permitted }\end{array}$ & $\begin{array}{l}\text { Commercial } \\
\text { Code Law. IFRS } \\
\text { permitted }\end{array}$ & & & & \\
\hline México & $\begin{array}{l}\text { IFRS for } \\
\text { consolidated } \\
\text { and separate } \\
\text { accounts } \\
\text { (other than for } \\
\text { financial } \\
\text { institutions) }\end{array}$ & $\begin{array}{l}\text { Converged } \\
\text { Mexican } \\
\text { Financial } \\
\text { Reporting Stds. } \\
\text { IFRS permitted }\end{array}$ & $\begin{array}{l}\text { Mexican Financial } \\
\text { Reporting Stds } \\
\text { plus other } \\
\text { requirements } \\
\text { established by } \\
\text { regulators }\end{array}$ & $\begin{array}{l}\text { Mexican } \\
\text { Financial } \\
\text { Reporting } \\
\text { Stds. } \\
\text { IFRS for SMEs } \\
\text { permitted }\end{array}$ & No & No \\
\hline Panama & $\begin{array}{l}\text { IFRS or USA } \\
\text { GAAP }\end{array}$ & IFRS & $\begin{array}{l}\text { IFRS or USA GAAP } \\
\text { required for } \\
\text { consolidated } \\
\text { accounts. For } \\
\text { non-consolidated } \\
\text { accounts IFRS } \\
\text { modified by } \\
\text { banking } \\
\text { prudential rules, } \\
\text { for regulatory } \\
\text { purposes }\end{array}$ & $\begin{array}{l}\text { IFRS for SMEs } \\
\text { permitted }\end{array}$ & No & No \\
\hline Peru & $\begin{array}{l}\text { IFRS except } \\
\text { for financial } \\
\text { institutions }\end{array}$ & $\begin{array}{l}\text { Large } \\
\text { companies are } \\
\text { required to use } \\
\text { IFRS }\end{array}$ & $\begin{array}{l}\text { Acctg stds issued } \\
\text { by the } \\
\text { Superintendence } \\
\text { of Banking, } \\
\text { Insurance and } \\
\text { Pension Fund } \\
\text { Administrators }\end{array}$ & $\begin{array}{l}\text { IFRS for SMEs } \\
\text { required }\end{array}$ & No & No \\
\hline Uruguay & $\begin{array}{l}\text { Full IFRS in } \\
\text { consolidated } \\
\text { accounts. } \\
\text { Converged } \\
\text { national acctg } \\
\text { stds for } \\
\text { separate } \\
\text { accounts }\end{array}$ & $\begin{array}{l}\text { Converged } \\
\text { national acctg } \\
\text { stds }\end{array}$ & Full IFRS & $\begin{array}{l}\text { IFRS ( of July } \\
\text { 2007) with } \\
\text { modifications }\end{array}$ & $\begin{array}{l}\text { No, but being } \\
\text { considered }\end{array}$ & $\begin{array}{l}\text { No, but being } \\
\text { considered }\end{array}$ \\
\hline Venezuela & $\begin{array}{l}\text { IFRS ( } 2008 \\
\text { version) with } \\
\text { modifications }\end{array}$ & $\begin{array}{l}\text { IFRS ( } 2008 \\
\text { version) with } \\
\text { modifications }\end{array}$ & $\begin{array}{l}\text { IFRS ( } 2008 \\
\text { version) with } \\
\text { modifications }\end{array}$ & $\begin{array}{l}\text { IFRS for } \\
\text { SMEs, other } \\
\text { than SMEs in } \\
\text { oil, energy } \\
\text { and mining } \\
\text { Industries } \\
\text { who are } \\
\text { required to } \\
\text { use full IFRS }\end{array}$ & No & No \\
\hline
\end{tabular}

\footnotetext{
*Foreign companies and Bolivian national companies that are subsidiaries of foreign companies are permitted to use IFRS for consolidation.

** The main adaptations are that banks must measure loan loss provisions using an expected loss approach and are prohibited from using the fair value option.
} 
Despite a collective policy of GLASS support for IFRS, there was a divergent reality: IFRS were not adopted in Bolivia and Guatemala. In the latter countries, international standards can only be adopted voluntarily and in a subsidiary manner. Local standards are maintained and IFRS are used only by a few companies. In El Salvador a reconciliation of the type suggested by Rodrigues and Craig (2007) can be observed: banks use national standards but highlight the main differences from IFRS through supplementary disclosures.

Institutional logics comprise a highly contingent set of social norms that drive behaviour through a logic of appropriateness. In most GLASS countries, full IFRS serve listed companies well (particularly in consolidated accounts). Unlisted companies use national standards or converged standards (e.g., in Argentina, Brazil, Bolivia, Guatemala, México and Uruguay). Several countries have adopted the IFRS for SMEs, while others have developed an additional local standard for micro-entities or a standard for cooperatives. Thus, to reconcile adoption with non-adoption, local standards appeared.

While some countries have adopted IFRS, others have preferred to converge and adapt IFRS to their national context (Brazil, Mexico and Argentina). Other countries have neither adopted nor converged (Bolivia and Guatemala). The adoption of IFRS is supported by the idea that IFRS provide comparability in financial information; and that countries without national accounting standards setting bodies can benefit from the adoption of standards that are ready for use (Whittington, 2005). The fact that GLASS now has a role in discussion about international accounting standards leads to belief that it is unnecessary to change accounting standards (as argued by the representative from Uruguay). The non-adoption or convergence is supported by belief that accounting is socially-constructed and that when companies are local, accounting standards must be adjusted to the local context. (The representatives of Argentina, Mexico and Brazil advocated convergence to suit different jurisdictions). In large countries with a powerful accounting profession, there was a process of convergence of local standards with IFRS. Such convergence results from a reconciliation between competitive logics (the need to adopt the best common-law accounting practices) and (the need to keep practices adjusted to the social context and code-law requirements).

Generally, large countries have more resources to effect convergence with IFRS. Despite adopting IFRS unchanged, some countries believe that they should have made some changes (e.g., Peru). Thus, the full adoption solution may not be associated with any conviction that the standards do not need adaptation, but from the absence of professional resources to do so.

\section{Were the adoption and convergence processes isomorphic? Which institutional logics were} central in these processes?

When only IFRS are permitted (but not required), only a few companies use them. Requirements to use IFRS constitutes a form of coercive isomorphism that is often effected by law or capital markets regulations. Organizations that represent major global institutional forces providing financial support (e.g., World Bank, International Monetary Fund) are sources of coercive isomorphism too. ${ }^{7}$ Coercive pressures from the IDB were important in GLASS countries where the accounting profession is less developed. In Bolivia, despite the support of the IDB in 2007, convergence or adoption has not yet occurred because of opposition from Government entities, particularly the National Tax Service. A similar institutional logic related

\footnotetext{
${ }^{7}$ Irvine (2008) concluded that the World Bank was an important source of coercive isomorphism in the United Arab Emirates.
} 
to taxation prevails in Guatemala. Thus, as Thornton and Ocasio point out (1999; 2008), historical patterns of cultural symbols, and assumptions, values and beliefs through which individuals and organizations give meaning to their daily activities, are shaping actions and preventing change. In Bolivia, different institutional logics have nested within higher social institutions (Thornton, 2002; Marquis \& Lounsbury, 2007) that offer resistance to change and prevent coercive isomorphism of the IDB from succeeding. In Guatemala, tax-related instrumental logics are causing companies to follow Guatemalan standards based on tax legislation. Thus, although institutional actors associated with the accounting profession support the logic of IFRS, local competitive tax-related logics appear to be stronger. Even though Bolivia and Guatemala are GLASS members, the lack of a strong institutional entrepreneur to lead the process nationally is slowing the adoption of IFRS. In other countries supported by the IDB, coercive isomorphism has been successful (e.g. Chile and Uruguay). In these cases, the dominant institutional logic has converged to the view that IFRS were important for free trade agreements. According to a key informant, the process of adopting IFRS is also regarded as likely to strengthen the accounting profession.

In many countries, the institutional logic of the financial sector is delaying full adoption of IFRS for banks and insurance companies (Argentina, El Salvador, Guatemala, Mexico and Peru). This is principally due to perceived problems with implementing fair value accounting by financial institutions. Thus, there are multiple sources of rationality. This reinforces the potential for any context to be influenced by competing and alternative logics (Scott et al., 2000). Although actors in the accounting profession seek power and economic advantage through the adoption of IFRS, the means and ends to achieve this outcome are constrained by other factors and existing institutional logics (Thornton \& Ocasio, 2008; Thornton et al., 2012).

The adoption of/convergence with IFRS is associated with the level of professional technical education (Guler et al., 2002; Hassan, 2008), the support of multinationals in the training process, and the role of higher education (normative pressures). While support from multinationals has occurred in almost all GLASS countries, the role of universities in supporting change varies greatly from country to country. According to some key informants, universities are delaying the process of change because the teaching of IFRS is far from widespread. In Brazil, although some universities teach IFRS, the key informant argued that Brazil has more than 1000 Higher Education Institutions, and the quality and curricula of institutions is disparate. International auditing firms have engaged heavily in normative isomorphism to promote adoption and convergence processes (Irvine, 2008).

A scarcity of professional accountants trained in IFRS has impeded material harmonization - as too has the lack of strong enforcement systems. In general, enforcement of standards in GLASS countries is achieved only through auditing procedures, stock exchange regulations, and professional association edicts. There is no system of fines for non-compliance. Knowing that audits in most countries are limited to large companies, and that the number of listed companies in Latin America is small, means control of the application of standards is limited. This is the case of Argentina, Chile, Mexico, Panama, Uruguay and Venezuela. Most key informants pointed out that professional associations and auditors do not have the capacity to monitor application of standards (e.g., in Brazil and Chile). In Peru, audit firms do not control compliance with IFRS. In Guatemala, Uruguay and Venezuela there is no enforcement system. In Peru, only the Securities Market Superintendence has established sanctions for noncompliance. In Bolivia (which has not yet adopted IFRS), compliance with accounting standards is the responsibility of the Authority for the Supervision and Social Control of Companies (part of the Ministry of Development and Economic Growth). Ecuador's enforcement system requires financial statements to be sent electronically to the Superintendence of Companies. 
Inspections are conducted randomly or only after a complaint against a company. A similar system exists in El Salvador.

Organizations adopt new practices for reasons of efficiency and legitimacy (Tolbert \& Zucker, 1983). If these new practices are inappropriate, and there is no enforcement, a mismatch arises between the standards they say they adopt, and the standards they actually do adopt (Nor-Aziah, 2007; Rodrigues \& Craig, 2007). The key informant from Brazil stated that companies were continuing to use Brazilian standards when they were expected to be using IFRS. Carvalho (2015) reported that of 120 companies analysed in the period 2008-2013 in Maranhão, Brazil, only three had adopted the IFRS for SMEs. This low frequency of adoption was due to a pervading "tax mentality." Such a decoupling is considered a natural rational reaction in contexts in which organizations seek legitimacy (Oliver, 1991). Loose coupling situations may also occur (Orton \& Weick, 1990) when a company responds only to selected requirements of international standards (Guerreiro et al., 2015). Given that the business and institutional environments of GLASS countries differ considerably from Anglo-Saxon countries, companies operate differently. It is important to improve the knowledge accounting professionals have of IFRS to increase isomorphism and avoid decoupling (Chand, 2005). In countries with weaker or non-existent enforcement systems, adoption may be a mere "label" and not a serious adoption (Daske et al., 2007; Carmona \& Trombetta, 2008; Guerreiro et al., 2015).

In Peru, the adoption of IFRS for SMEs has not been completed efficiently. There has been a decoupling because of a lack of resources, a "tax mentality", and a lack of training in IFRS (Nakasone, 2015). Peru has sanctions only for listed companies. Audit firms do not control compliance with accounting standards. Therefore, decoupling is unsurprising.

The deinstitutionalisation of local standards in countries which support adoption of IFRS is not evident. There seems to be no consensus among the actors (in particular, related to banking, insurance and tax authorities), leading to a lack of institutional coherence (Oliver, 1992). Only when the institutional logic of IFRS is accepted socially will there be institutional change and more widespread adoption of IFRS.

Thus, the increase of isomorphism in relation to IFRS in the region will depend on the ability of the organizational sector to have knowledge-power discourses that influence the political-economic sector in the region (Rodrigues \& Craig, 2007; Dillard et al., 2004). This will help to reduce the "tax mentality", improve IFRS teaching, and create enforcement systems that make the adoption/convergence with IFRS effective.

4. Does the degree of adoption or convergence depend on whether knowledge discourses about IFRS became power? Who were the institutional actors? What are the main sources of resistance?

Power-knowledge discourses can change institutional logic that resists the adoption of IFRS. This leads to belief that IFRS are neutral regarding tax collection or that the risk of financial institutions will not increase by adopting international standards. Power-knowledge discourses in favor of IFRS are essential to increase the degree of formal isomorphism in the adoption of standards (Rodrigues \& Craig, 2007). In Bolivia and Guatemala, institutional actors linked to the profession (organizational level) seem unable to make the change on their own, but require support of the state (political-economic level). These key informants reported regretting that the IASB cannot directly impose IFRS in national contexts. This poses a challenge to IFRS Foundation trustees to engage politically with governments: for example, the 
Brazilian key informant pointed out that they should argue that "Brazil cost"8 would be reduced.

In Brazil, the adoption/convergence of IFRS has provided grounds for the Brazilian accounting profession to negotiate successfully for a higher social status with the government. Admission to the profession can now only be made by graduates with higher education in accounting, ending admission of "accounting technicians." Additionally, they negotiated the right to impose a professional entry examination ("Exam of Sufficiency") and an unequivocal right to issue accounting standards. As a consequence of convergence with IFRS, audit fees grew 20.71\% between 2009 and 2012 in companies listed on Bolsa de Valores, Mercadorias e Futuros de São Paulo, a stock exchange located at São Paulo, Brazil (Murro et al., 2015).

The interviews revealed that stronger power-knowledge discourses in favour of IFRS were associated with countries which tended to accept the costs of adopting IFRS as irrelevant. Several countries favoured adoption of IFRS for efficiency reasons related to reduction of standardization costs. Some countries have never had local accounting standards. In other countries there were no accounting standards on some matters. The permanent updating of IFRS was considered important since it would decrease standardization costs. However, some discourses point to the high quality of IFRS and to the perception that adoption of IFRS was a sign of modernity in a country because IFRS represent "best accounting practices." Discourses associated with the idea that better accounting standards lead to modernization of the accounting profession were also considered important explanations of change (Rodrigues \& Craig, 2007; Guerreiro et al., 2012a). Some key informants said that adoption was influenced by rhetorical discourses that claimed IFRS will lead to improved business activity and competitiveness. Other key informants acknowledged the rhetoric associated with the benefits of change. For example, the Panamanian key informant argued that accounting cannot change a country's economy, since accounting is "always a step beyond economic events."

Professional accounting bodies in Chile, El Salvador, Guatemala and Venezuela were institutional entrepreneurs. Another major agent of change was government (in Peru and Uruguay), often through the stock exchange regulatory body. In Brazil, decisions regarding IFRS were imposed by the government through the CVM. In Ecuador, the stock exchange regulator was the main entrepreneur. In Colombia, the adoption process was led by the accounting profession, supported by the government. In Panama, it was led by audit firms, supported by banking law and securities law, which both required use of IFRS. Thus, these institutional entrepreneurs are interested in particular institutional arrangements. They mobilize resources to create new institutions or transform existing ones (Maguire et al., 2004). Stock exchanges wanted efficient and transparent functioning of capital markets. The accounting profession aspired to a rise in social status that would accrue from using higher quality and more sophisticated standards. Governments believed that modernization of the economy, and globalization of companies, depended on the adoption of IFRS (Guerreiro et al., 2015). The IDB, through an IMF program, was an important institutional actor. It supported the move to IFRS in Bolivia, Chile and Uruguay. Despite the IDB's resource support, this was insufficient in Bolivia for IFRS to be accepted, since support of the tax authority and the government was lacking. So, although resources are important in implementing change, it is also important that the state enforces standards.

8 "Brazil cost" refers to the increased operating costs associated with doing business in Brazil. Several factors contribute to the extra cost: high levels of public deficits, the operation of cartels, inefficient public services, high real interest rates, excessive bureaucracy for importers and exporters, low education levels, and a lack of qualified labour. 
The adoption or convergence of IFRS in GLASS countries resulted from discourses of institutional entrepreneurs (mainly the accounting profession, state, and stock exchange) which controlled the resources needed to make the change (Greenwood \& Suddaby, 2006). However, the harmonization process is far from complete. Important obstacles still impair genuine comparability. Some of the obstacles "are deeply cultural, while others are susceptible to modulation by the principal parties" Zeff (2007, p. 302). Such modulation can occur through power-knowledge discourses (Rodrigues \& Craig, 2007) and power strategies to influence stakeholders' perceptions of the legitimacy of an IFRS system (Fontes et al., 2016).

When there is no consensus about a given practice, resistance is expected (Oliver, 1992). Because our 13 key informants are from countries that volunteered to form a regional group at the suggestion of the IASB, organizational resistance was not expected. However, some resistance was observed to the IFRS standard for SMEs because the adoption of this standard would lead to revoking national standards. Tax authorities were an obstacle to change in countries with a strong link between accounting and taxation, because of strong concerns that tax collections would be reduced. In such countries, previous national accounting standards were linked closely to taxation. They have been shaped by a different logic - one which poses a threat to the adoption of IFRS. In some GLASS countries, the fact that IFRS use the concept of fair value, extensively, conflicts with the logic of the finance sector which believes their risk exposure will be higher than when using national standards.

Data at the organizational field level reveal that translation of accounting standards does not create difficulties, despite some countries' use of a localised version of Spanish (e.g., Chile). Colombia uses the IASB translation for Spanish, but some words are difficult to understand. Accounting professionals with superior technical knowledge have found some accounting standards are poorly specified and use vague language. Zeff (2007) reported difficulties in interpreting standards, even when they were well translated according to the context. For example, Zeff noted cultural differences in the definition of the word "probable" in some countries.

\section{Discussion}

The regional accounting standardization body, GLASS, was promoted by the institutional entrepreneurship of the IASB. The formation of regional groups such as GLASS is intended to promote reconciliation regarding accounting standards. GLASS helped to improve the convergence process by increasing mimetic and normative isomorphism.

The GLASS countries are at different stages of development of accounting standards, with many competing viewpoints. In Bolivia and Guatemala, IFRS are not permitted but are adopted voluntarily by some companies in consolidated accounts. Logics prompted by the government's fear of decreases in tax paid by companies prevented a stronger commitment to IFRS. Banks and financial institutions in some GLASS countries have resisted moving to IFRS. They are concerned about the technical complexity of standards relating to financial instruments, and the effect of widespread adoption of fair value accounting.

The lack of training for accountants in GLASS countries raises the question of whether change will be effective, or whether it will only be cosmetic. Given that the institutional context in Latin America differs from the Anglo-Saxon context, decoupling or loose-coupling is possible. Without a good system of enforcement there is likely to be a considerable distance between formal harmonization and material harmonization (Fontes et al., 2005). Although IFRS have been adopted or converged in most GLASS countries with the support of national professional and standard setting organizations, companies may not comply, and former national models of standard setting seem to be prevailing. The problems of adopting IFRS were 
identified by key informants as technical complexity, cultural barriers in understanding the Anglo-American accounting model, the lack of competent accounting professionals for implementation, and the reluctance of some universities to teach IFRS.

Important logics promoting the adoption of IFRS involved efficiency discourses. These included the reduction of consolidation costs and improved comparability (competitive isomorphism); and modernization of a country and its economy through higher quality standards (legitimacy discourse). Thus, the actors involved undertook change based on discourses which developed the idea that IFRS should be implemented to increase efficiency and the legitimacy of companies. The main actors undertaking the change were the accounting professions, the stock exchanges and the State. Large countries with more resources and a better established accounting profession (Argentina, Brazil and Mexico) are converging their standards with IFRS. Smaller and less well-resourced countries consider that adoption of IFRS will provide standards that are ready, of high quality, and conducive to producing uniformity.

The institutionalization of international accounting standards is a deeply political activity that reflects the relative power of organized interests and actors (Dillard et al., 2004). The degree of convergence or adoption will depend on the power of the discourse about IFRS. Institutional entrepreneurs have to use power-knowledge discourses and resources to support this change (DiMaggio, 1988). Thus, the successive agreements between competing viewpoints formed over time depend on developing a shared vision, the impact of power-knowledge discourses, the capacity to mobilize people and resources to support and accept new routines, and the capacity to motivate others to sustain change (Rodrigues \& Craig, 2007).

This paper contributes to the thin volume of literature on the application of IFRS in Latin America. In terms of theory development, this paper extends Rodrigues and Craig (2007) by incorporating institutional logics and institutional entrepreneurship in an institutional framework to explain change and resistance to change. This study highlights the different stages of the adoption and convergence with IFRS in GLASS countries, the institutional logics associated with change and resistance to change, and the difficulties associated with the change process. The institutional entrepreneurs in each country are identified.

The approach adopted here can be used to explain the institutionalization processes of adoption/convergence in other regional accounting standards setting bodies, allowing comparisons of the institutional dynamics between different regions. Further research could follow the process of international accounting harmonization in Latin America to observe how agreements between competing viewpoints change over the time as a consequence of the power strategies of organizational actors. Although the process of convergence and adoption of IFRS has commenced in many GLASS countries, studies that explore the effective degree of compliance with standards are important, since the enforcement systems in GLASS countries are weak. Future qualitative studies might follow Guerreiro et al. (2015) in trying to understand deeply, for each of the adopter countries analyzed, how IFRS were communicated between the political-economic level, organizational field level and organization level.

\section{References}

Battilana, J., 2006. Agency and institutions: the enabling role of individuals social position. Organization, 13 (5), 653-676.

Battilana, J., Leca, B., Boxenbaum, E., 2009. How actors change institutions: Towards a theory of institutional entrepreneurship. Academy of Management Annals, 3 (1), 65-107.

Carmona, S., Trombetta, C., 2008. On the global acceptance of IAS/IFRS accounting standards: The logic and implications of the principles-based system. Journal of Accounting and Public Policy, 27, 455-461. 
Carpenter, V., Feroz, E., 1992. GAAP as a symbol of legitimacy: New York state's decision to adopt generally accepted accounting principles. Accounting, Organizations and Society, 17 (7), 613-643.

Carvalho, J.C.de A., 2015. Difficulties in the adoption of IFRS on small and medium enterprises (SMEs). In Lourenço, I., Major, M.J., Standardization of Financial Reporting and Accounting in Latin American Countries, Chapter 12. Hershey: IGI Global.

Chand, P., 2005. Impetus to the success of harmonization: the case of South Pacific Islands Nations. Critical Perspectives on Accounting. 16 (3), 209-26

Daske, H., Hail, L., Leuz, C., Verdi, R., 2013. Adopting a label: Heterogeneity in the economic consequences around IAS/IFRS adoptions. Journal of Accounting Research, 51, 495-547.

Dillard, J.F., Rigsby, J.T., Goodman, C., 2004. The making and remaking of organizational context: duality and the institutionalization process. Accounting, Auditing \& Accountability Journal, 17, 506-542.

DiMaggio, P.J., 1988. Interest and agency in institutional theory. In L.J. Zucker (Ed.), Institutional patterns and organizations: Culture and environment (pp. 3-21). Cambridge: Ballinger.

DiMaggio, P.J., Powell, W.W., 1983. The iron cage revisited: institutional isomorphism and collective rationality in organizational fields. American Sociological Review, 48, 147-160.

Doupnik, T., Perera, H., 2007. International Accounting. New York: McGraw-Hill/Irwin.

Fontes, A., Rodrigues, L. L., Craig, R., 2016. A theoretical model of stakeholder perceptions of a new financial reporting system. Accounting Forum, 40(4), 300-315).

Fontes, A., Rodrigues, L.L., Craig, R., 2005. Measuring convergence of national accounting standards with international financial reporting standards. Accounting Forum, 29 (4), 415436.

Friedland, R., Alford, R.R., 1991. Bringing society back in: Symbols, practices, and institutional Contradictions. In Powell W.W., DiMaggio, P.J., (Eds.). The New Institutionalism in Organizational Analysis, (pp. 232-266). Chicago: University of Chicago Press.

Greenwood, R., Suddaby, R. 2006. Institutional entrepreneurship in mature fields: The big five accounting firms. Academy of Management Journal, 49, 27-48.

Guerreiro, M.S., Rodrigues L.L., Craig, R., 2012a. Voluntary adoption of International Financial Reporting Standards by large unlisted companies in Portugal: institutional logics and strategic responses. Accounting, Organizations and Society, 37, 482-499.

Guerreiro, M.S., Rodrigues, L.L., Craig, R., 2012b. Factors influencing the preparedness of large unlisted companies to implement adapted International Financial Reporting Standards in Portugal. Journal of International Accounting, Auditing and Taxation, 21, 169- 184.

Guler, I., Guillen, M., Macpherson, J., 2002. Global competition, institutions, and the diffusion of organizational practices: The international spread of ISO 9000 quality certificates. Administrative Science Quarterly, 47, 207-232.

Hassan, M., 2008. The development of accounting regulations in Egypt. Managerial Auditing Journal, 23, 467-484.

Irvine H.J., 2008. The global institutionalization of financial reporting: The case of the United Arab Emirates, Accounting Forum 32 (2), 125-142.

Lounsbury, M., 2007. A tale of two cities: Competing logics and practice variation in the professionalizing of mutual funds. Academy of Management Journal, 50, 289-307.

Lounsbury, M., 2008. Institutional rationality and practice variation: New directions in the institutional analysis of practice. Accounting, Organizations and Society, 33, 349-361. 
Maguire, S., Hardy, C., Lawrence, T.B., 2004. Institutional entrepreneurship in emerging fields: HIV/AIDS treatment advocacy in Canada. Academy of Management Journal, 47 (5), 657679.

Marquis, C., Lounsbury, M., 2007. Vive la résistance: Competing logics and the consolidation of U.S. community banking. Academy of Management Journal, 50, 799-820.

Miller, P., 1994. Accounting as a social and institutional practice: an introduction, In A.G. Hopwood and P. Miller (Eds.) Accounting as Social and Institutional Practice (pp. 1-39), Cambridge: University Press.

Miller, P., Napier, C., 1993. Genealogies of calculation. Accounting, Organizations and Society, 18(7/8), 631-647.

Murro, E.V.B., Munhoz, T.R., Teixeira, G.B., Lourenço, I., 2015. The impact of the mandatory adoption of IFRS in the fees of auditing in companies of BM\&F Bovespa. In Lourenço, I., Major, M.J., Standardization of Financial Reporting and Accounting in Latin American Countries, Chapter 8. Hershey: IGI Global.

Nakasone, G., 2015. Accounting standards in Peru: Issues and challenges. In Lourenço, I. and Major, M.J. Standardization of Financial Reporting and Accounting in Latin American Countries. Hershey: IGI Global.

Nor-Aziah, A.K., Scapens, R.W, 2007. Corporatisation and accounting change: The role of accounting and accountants in a Malaysian public utility. Management Accounting Research 18 (2), 209-247.

Oliver, C., 1992. The antecedents of deinstitutionalization. Organization Studies, 13, 563-588.

Orton, J.D., Weick, K.E., 1990. Loosely coupled systems: a reconceptualization. Academy of Management Review, 15, 203-223.

Patton, M.Q., 2002. Qualitative Research and Evaluation Methods. California, USA: Sage.

Radebaugh, L., Gray, S., Black, E., 2006. International Accounting and Multinational Enterprises. New York, NY: Wiley.

Rathkte, A., Santana, V., 2015. Has IFRS improved comparability regarding earnings management in Latin America? In Lourenço, I. and Major, M.J. Standardization of Financial Reporting and Accounting in Latin American Countries. Hershey: IGI Global.

Rodrigues, L.L., Craig, R., 2007. Assessing international accounting harmonization using Hegelian dialectic, isomorphism and Foucault. Critical Perspectives on Accounting, 18 (6), 739-757.

Rodríguez García, M.d.P., Alejandro, K.A.C., Sáenz, A.B.M., Sánchez, H.H.G., 2017. Does an IFRS adoption increase value relevance and earnings timeliness in Latin America? Emerging Markets Review, 30, 155-168.

Ryan, B., Scapens, R., Theobald, M., 2002. Research Method and Methodology in Finance and Accounting. London, UK: Thompson.

Sarquis, R.W., Luccas, R.G., Lourenço, I., 2014. Classificação dos Sistemas Contábeis na era IFRS: uma análise dos países da América Latina. São Paulo. XIV Congresso USP de Controladoria e Contabilidade, October.

Scott, W.R, Meyer, J.W., 1991. The Organization of Societal Sectors: Propositions and Early Evidence. In Powell, W.W. \& DiMaggio, P.J. The New Institutionalism in Organizational Analysis (pp. 108-140). Chicago, IL: University of Chicago Press.

Scott, W.R., Ruef, M., Mendel, P.J., Garonna, G.A., 2000. Institutional Change and Healthcare Organizations. Chicago: University of Chicago Press.

Silva, C.B.A., Madeira, G.J., Assis, J.L.F., 2004. Harmonização de normas contábeis: um estudo sobre as divergências entre normas contábeis internacionais e seus reflexos na contabilidade brasileira. Revista Contemporânea de Contabilidade, 1 (1), 115-139. 
Silva, A., Pletsch, C., Klann, R., Fasolin, L.,Scarpin, J.E., 2015. Influence of international accounting convergence on the level of earnings management in both Brazilian and Chilean Companies. In Lourenço, I., Major, M.J. (Eds.). Standardization of Financial Reporting and Accounting in Latin American Countries. Hershey: IGI Global.

Tolbert, P.S., Zucker, L.G., 1983. Institutional sources of change in the formal structure of organizations: The diffusion of civil service reform, 1880-1935. Administrative Science Quarterly, 28, 22-39.

Thornton, P.H., Ocasio, W., 2008. Institutional Logics. In R. Greenwood, C. Oliver, K. Sahlin \& R. Suddaby (Eds.). The Sage Handbook of Organizational Institutionalism (pp.99-129). Thousand Oaks, CA: Sage.

Thornton, P.H., Ocasio, W., Lounsbury, M., 2012. The Institutional Logics Perspective: A New Approach to Culture, Structure, and Process. New York: Oxford University Press.

Whittington, G., 2005. The adoption of international accounting standards in the European Union. European Accounting Review, 14 (1), 127-153.

Zeff, S.A., 2007. Some obstacles to global financial reporting comparability and convergence at a high level of quality. British Accounting Review, 39 (4), 290-302. 